\title{
GMR
}

\section{Ability of HMGB1 protein to bind to intrinsically bent and non-bent DNA sites in the $A M P D 2$ gene amplicon}

\author{
K.J.R. Passos, A. Fiorini, F.R. Rosado, D.V.B. Freitas, Q.A. Lima Neto, \\ J.R. Pattaro Junior, V.P. Gaspar and M.A. Fernandez \\ Departamento de Biologia Celular e Genética, Universidade Estadual de Maringá, \\ Maringá, PR, Brasil \\ Corresponding author: M.A. Fernandez \\ E-mail: mafernandez@uem.br \\ Genet. Mol. Res. 15 (2): gmr.15027441 \\ Received August 13, 2015 \\ Accepted October 2, 2015 \\ Published June 10, 2016 \\ DOI http://dx.doi.org/10.4238/gmr.15027441
}

\begin{abstract}
HMGB-like proteins are architectural chromatin factors, and their function is heavily dependent on their ability to interact with DNA (especially non-canonical DNA structures). HMGB1 is involved in many DNA processes, and dysregulation of HMGB protein expression has profound effects on cellular transcription, resulting in severe developmental defects as well as cancer. During DNA replication, elements that form the origin are still not well defined in metazoans. Sites with A (adenine) or $\mathrm{T}$ (thymine) repeats cause intrinsic curvatures in the DNA and are described to be involved in the replication machinery by providing binding sites to replication proteins. As a result, the DNA molecule shows intrinsically bent DNA sites, caused by periodic repeats of 2 or more $\mathrm{As} / \mathrm{Ts}(\mathrm{dA} / \mathrm{dT})$ as well as intrinsically non-bent DNA sites (INBDs), due to a succession of curvatures that cancel each other. In the present study, we mapped 11 INBDSs present in the $A M P D 2$ gene that are related to each replication origin (ori $G N A I 3$, ori $C$, ori $B$, and $\operatorname{ori} A$ ). Following characterization of
\end{abstract}


INBDSs, we tested the ability of HMGB1 to bind to the bent $(b 1, b 2$, $b 4 a, b 4 b, b 5, b 6, b 7$, and $b 8)$ and non-bent DNA fragments ( $n b 7, n b 11$, $n b 1, n b 2, n b 4$, and $n b 5)$ via electrophoretic mobility shift assays. All fragments showed efficient binding to HMGB1. However, the non-bent DNA fragments $n b 2, n b 4$, and $n b 5$ showed slightly reduced binding efficiency.

Key words: HMGB1; Intrinsically bent DNA; AMPD2 amplicon; Intrinsically non-bent DNA; DNA replication

\section{INTRODUCTION}

Chromosomal DNA must be precisely duplicated in order to avoid alterations that could lead to tumors and/or other cell disorders. Given the large size of the eukaryotic DNA, many replication forks are required for efficient DNA synthesis; therefore, meticulous regulation is extremely important (Shen, 2011). It is also vital that replication origins are not initiated more than once per cell cycle, which could cause a re-duplication, leading to genetic recombination (Blow and Gillespie, 2008). Most tumor cells in humans show some degree of chromosomal alteration, and can be divided in two groups: those that lack cell cycle regulation, resulting in chromosomal instability, and those that show punctual mutations in genes related to maintenance of genetic integrity, such as proteins that regulate DNA replication and repair (Tourrière and Pasero, 2007).

HMGB-like proteins are architectural chromatin factors and facilitate the formation of nucleoprotein complex structures (Grasser et al., 2007). The function of the HMGB1 proteins is dependent on their ability to interact with DNA (especially distorted DNA structures or pre-bent DNA) and induce structural changes in specific DNA targets (Stros et al., 1994; Stros, 1998).

HMGB mammalian proteins contain two DNA binding domains, A and B HMG-boxes, as well as an acidic tail that is variable in size. The A and B boxes bind to the minor groove of DNA, where the A box has a much greater preference for distorted DNA structures. The acid tail decreases the affinity of the protein for DNA (Stros et al., 1994; Thomas and Travers, 2001).

HMGB1 is involved in many processes such as DNA replication, repair, recombination, site-specific genomic integrity, and transcription (Agresti and Bianchi, 2003; Bianchi and Agresti, 2005). Dysregulation of HMG protein expression and the type of HMG have profound effects on cellular transcription, resulting in severe developmental defects and cancer (Hock et al., 2007).

The DNA molecule shows structures such as four-way junctions and loops (Homberger, 1989), as well as curvatures called intrinsically bent DNA sites (IBDSs) (Anderson, 1986). Another related structure, the intrinsically non-bent DNA sites (INBDs), is the result of a succession of curvatures that cancel each other, producing linear DNA (Anderson, 1986; Eckahl and Anderson, 1990; Mollegaard et al., 2005).

The DNA elements that make up a replication origin in metazoans are still not well defined. When identifying structural motifs that could be involved in replication initiation, sites with consecutive As or Ts that form intrinsic curvatures in the DNA are described as being involved in the replication machinery, as they provide binding sites for replication proteins (Segal and Widom, 2009a; 2009b).

In prokaryotes, IBDSs have been found to be associated with promoter activity as well as replication origins (Gimenes et al., 2008). In eukaryotes, IBDS have also been associated 
with replication initiation origin sites (Fiorini et al., 2001, 2006a; Lima Neto et al., 2014). Moreover, there are indications that these structures are relevant to transcription (Fiorini et al., 2001), nucleosome condensation (Virstedt et al., 2004), recombination events (Milot et al., 1992), fragile genomic sites (Palin et al., 1998), nuclear matrix association sites (MARs), and MARs associated to replication origins (Anderson 1986, Fiorini et al., 2006b).

The AMPD2 gene amplicon is composed of the genes GNAI3, GNAT2, AMPD2, and GSTM4. Between GNAI3 and GNAT2 is the oriGNAI3, a preferential replication initiation region (Toledo et al., 1998; Anglana et al., 2003). Although there are other replication origins (oriA, ori $B$ e ori $C$ ) on the same segment, they only seem to be activated when oriGNAI3 efficiency is reduced (Anglana et al., 2003). The localization of the oriGNAI3 replication origin in the given segment was determined by the two dimensional electrophoresis method (Toledo et al., 1998) and later confirmed by molecular combing (Anglana et al., 2003; Debatisse et al., 2004).

In this study, in silico mapping of INBDSs was performed in the amplified mammalian $A M P D 2$ gene domain. Characterizations of these regions in IBDS have previously been performed (Lima Neto et al., 2014). We also analyzed binding efficiency of HMGB1 protein to bent and non-bent DNA fragments mapped in the $A M P D 2$ gene (ori $A$, ori $B$ e ori $C$, oriGNAI3).

\section{MATERIAL AND METHODS}

\section{Biological material}

The amplified region of the AMPD2 gene (Figure 1), from Chinese hamster has approximately $70 \mathrm{~kb}$ and was kindly provided by Dr. Michelle Debatisse (Institute Curie, Paris, France). DH5 $\alpha$ Escherichia coli competent cells were transformed with vectors containing DNA fragments by heat shock or electroporation (Sambrook and Russell, 2001). The recombinant DNA was obtained from bacteria cultured for $16 \mathrm{~h}$ at $37^{\circ} \mathrm{C}$ in Luria-Bertani liquid medium by the cetyltrimethylammonium bromide (CTAB) extraction method and/or by the alkaline lysis method (Sambrook and Russell, 2001).

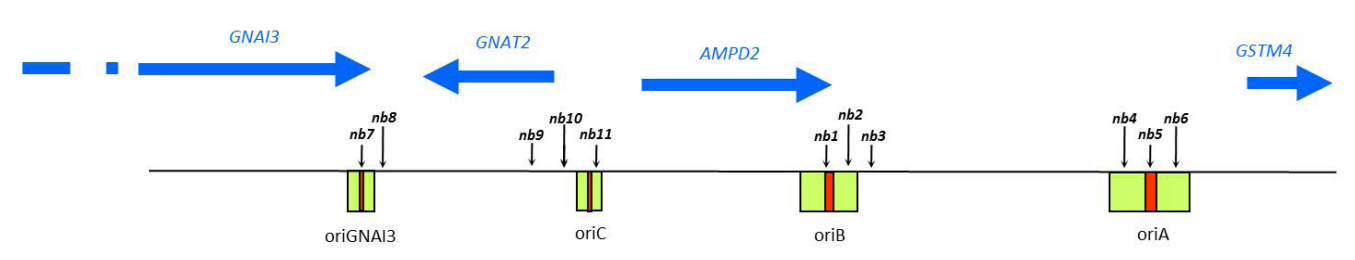

Figure 1. In silico analysis of non-bent fragments. The three-dimensional simulations were performed using the $3 \mathrm{D} 15 \mathrm{~m} 1$ program, based on the nucleotide sequence of each fragment.

\section{In silico mapping of INBDSs}

Lima Neto et al. (2014) mapped IBDSs from the DNA replication origins oriGNAI3, ori $C$, ori $B$, and ori $A$ in the amplified mammalian $A M P D 2$ gene domain. The non-bent DNA fragments (Table 1) were selected by in silico analysis of replication initiation sites and flanking sequences from the amplified AMPD2 gene. The analyses were performed through computational analysis with Map15a and 3D15m1 programs (Bolshoy et al., 1991; Pasero et al., 1993), using the algorithm described by Eckahl and Anderson (1987). 
Table 1. Non-bent DNA sites and primer sequences.

\begin{tabular}{|c|c|c|c|}
\hline $\begin{array}{l}\text { Replication } \\
\text { Origin }\end{array}$ & Nomenclature & $\begin{array}{l}\text { Product } \\
\text { Size (bp) }\end{array}$ & Forward $(\mathrm{F})$ and Reverse $(\mathrm{R})$ Primers \\
\hline oriGNAI3 & $n b 7$ & 124 & $\begin{array}{l}\text { F: 5'-ACTGTCGACGAATGTGCACTTATGGGGAT-3' } \\
\text { R: 5'-AGTTCTAGAAAATGATATAAGCCAGACCACAC-3' }\end{array}$ \\
\hline oriGNAI3 & $n b 8$ & 102 & $\begin{array}{l}\text { F: 5'-ACTGTCGACCCCTGCTGGAATCTGTGCTC-3' } \\
\text { R: 5'-AGTTCTAGAGGAGGGAGGTGAAGGGGGAAGA-3' }\end{array}$ \\
\hline oriC & $n b 9$ & 99 & $\begin{array}{l}\text { F: 5'-ACTGTCGACCAGCCCCCATCAACCCACCA-3' } \\
\text { R: 5'-AGTTCTAGACTGCTATTGCTTGGTGAGTG-3' }\end{array}$ \\
\hline oriC & $n b 10$ & 109 & $\begin{array}{l}\text { F: 5'-ACTGTCGACTCTCATCTTCCTTTGCCCAC-3' } \\
\text { R: 5'-AGTTCTAGAATCTTCGACTGGGAAAGC-3' }\end{array}$ \\
\hline oriC & nb11 & 103 & $\begin{array}{l}\text { F: 5'-ACTGTCGACTTATGGTCACATGGTACCTG-3' } \\
\text { R: 5'-AGTTCTAGAGAAGCCGGCCCTTAGACATT-3' }\end{array}$ \\
\hline ori $B$ & $n b l$ & 115 & $\begin{array}{l}\text { F: 5'-CTGTCGACTGGTGACAGACATCACTGT-3' } \\
\text { R: 5'-AGTTCTAGAGTGAATTGCTAGAGATAAA-3' }\end{array}$ \\
\hline ori $B$ & $n b 2$ & 99 & $\begin{array}{l}\text { F: 5'-ACTGTCGACGGAGATAGATGCACACCCCA-3' } \\
\text { R: 5'-AGTTCTAGAGGCCATGCTTCAACCGCAGG-3' }\end{array}$ \\
\hline ori $B$ & $n b 3$ & 103 & $\begin{array}{l}\text { F: 5'-ACTGTCGACACATTAAGATGTCTATTTC-3' } \\
\text { R: 5'-AGTTCTAGATTTATGAGAGGTCTGGCAA-3' }\end{array}$ \\
\hline ori $A$ & $n b 4$ & 94 & $\begin{array}{l}\text { F: 5'-ACTGTCGACACAAAGAAAGTGATGATCCA-3' } \\
\text { R: 5'-AGTTCTAGAGGCATCTATTTACATGCTT-3' }\end{array}$ \\
\hline ori $A$ & $n b 5$ & 101 & $\begin{array}{l}\text { F: 5'-ACTGTCGACCAGGAGGCTAAGGCCAGCTT-3' } \\
\text { R: 5'-AGTTCTAGATTGGTTTTGTTGAGACAGTC-3' }\end{array}$ \\
\hline ori $A$ & $n b 6$ & 98 & $\begin{array}{l}\text { F: 5'-ACTGTCGACAAGTCTCGAGGACTCTTCT-3' } \\
\text { R: 5'-AGTTCTAGAAACCAGAGCACATTTACAAT-3' }\end{array}$ \\
\hline
\end{tabular}

\section{Amplification of non-bent DNA fragments by polymerase chain reaction}

Regions containing non-bent DNA segments that were selected by computational analysis were amplified by polymerase chain reaction (PCR) in a final volume of $15 \mu \mathrm{L}$ using $2.5 \mathrm{mM}$ dNTP mix, $100 \mathrm{ng}$ DNA, 25 pmol of each primer (Table 1), 1X PCR buffer (with 1.5 $\mathrm{mM} \mathrm{MgCl} 2$ ), and 1 unit TaqDNA Polymerase (Invitrogen ${ }^{\circledR}$ ). The amplification conditions were as follows: $1 \mathrm{~min}$ at $94^{\circ} \mathrm{C}, 1 \mathrm{~min}$ at $62^{\circ} \mathrm{C}$, and $1 \mathrm{~min}$ at $72^{\circ} \mathrm{C}$, for a total of $35 \mathrm{cycles}$, followed by final extension for $10 \mathrm{~min}$ at $72^{\circ} \mathrm{C}$.

\section{Subcloning of non-bent DNA segments and sequencing of recombinant plasmids}

PCR products were initially cloned into the pGEM vector (Promega) and transformed into DH5 $\alpha$ competent $E$. coli cells. Successful transformations were selected on plates of solid Luria-Bertani medium containing $0.04 \mathrm{mg} / \mathrm{mL} \mathrm{X-gal} \mathrm{and} 50 \mathrm{mg} / \mathrm{mL}$ ampicillin, as described by Sambrook and Russell (2001).

Five white colonies were selected, and the recombinant DNA was isolated by minipreparation of plasmid DNA via the CTAB method (Sambrook and Russell, 2001). Verification was carried out by cleavage with the restriction enzyme EcoRI to release the insert from the vector pGEM polylinker. The cleavage products were visualized by electrophoresis on $1.5 \%$ agarose gels using $1 \mathrm{X}$ TBE buffer $(45 \mathrm{mM}$ Tris-borate, $1 \mathrm{mM}$ ethylenediaminetetraacetic acid [EDTA], pH 8.0), and a 100-bp ladder (Biolabs) was used as the molecular weight standard. Cloning was further confirmed by sequencing using the DYEnamic ET terminator kit (Amersham Biosciences) with universal and reverse M13 primers in 1000 MegaBACE equipment.

\section{Electrophoretic behavior analysis of non-bent DNA fragments}

Non-bent DNA fragments were released from pGEM vector after cleavage with 
EcoRI enzyme (Biolabs) and were analyzed according to their electrophoretic behavior in $12 \%$ polyacrylamide gels with $1 \mathrm{X}$ TBE buffer at $4^{\circ} \mathrm{C}$. A 25-bp DNA ladder (Invitrogen) was used as the molecular weight marker. The voltage and running time employed were determined according to amplicon size. Following electrophoresis, gels were stained with $1 \mathrm{mg} / \mathrm{mL}$ ethidium bromide (Invitrogen) for $30 \mathrm{~min}$ and were exposed to UV light via the UVP Bioimaging photo documentation system. Band sizes were determined by comparison with the DNA ladder using the software Loccus Biotechnology. The $R$-values, which correspond to the ratio of the observed fragment length and the expected length, were calculated for each DNA fragment to determine its mobility: $R$-values between 0.90 and 1.10 indicated no alteration in fragment mobility, and $R$-values $\geq 1.11$ indicated reduced mobility (Norberto de Souza and Ornstein, 1998).

\section{Protein expression and purification}

The HMGB1 mammalian protein was expressed using the pQE-80L vector and was purified from the E. coli DH5 $\alpha$ strain (de Oliveira et al., 2006). The HMGB1 protein, cloned into the expression vector, was kindly provided by Dr. Marcelo R. Fantappié from Instituto de Bioquímica Médica da Universidade Federal do Rio de Janeiro. The purity of the HMGB1 protein was confirmed by $12 \%$ sodium dodecyl sulfate-polyacrylamide gel electrophoresis followed by Coomassie Blue R-250 staining. Protein concentration was determined using the Pierce $^{\mathrm{TM}}$ BCA Protein Assay Kit (Thermo Scientific).

\section{Electrophoretic mobility shift assay}

Electrophoretic mobility shift assays (EMSAs) were carried out as described by Ribeiro et al. (2012) with modifications. The selected fragments were as follows: bent fragments $b 1$ and $b 2$ and non-bent fragment $n b 7$ for oriGNAI3; bent fragments $b 4 a$ and $b 4 b$ and non-bent fragment $n b 11$ for oriC; bent fragments $b 5$ and $b 6$ and non-bent fragments $n b 1$ and $n b 2$ for ori $B$; bent fragments $b 7$ and $b 8$ and non-bent DNA fragments $n b 4$ and $n b 5$ for ori $A$.

DNA fragments were obtained by PCR amplification, as described above. The bent DNA fragments and the primers sequences used for DNA amplification were as described by Lima Neto et al. (2014). DNA fragments were purified by the ethanol/ $\mathrm{NaCl}$ precipitation method (Sambrook and Russell, 2001) and quantified using the NanoDrop 2000c (Thermo Scientific).

Fifty nanograms of each fragment was mixed with increasing amounts $(0,250$, and 500 ng) of HMGB protein diluted in buffer A $(0.14 \mathrm{M} \mathrm{NaCl}, 20 \mathrm{mM}$ Tris-HCl, $\mathrm{pH}$ 7.5, $0.2 \mathrm{mM}$ EDTA, $\mathrm{pH}$ 8.0, $5 \mathrm{mM}$ DTT) in a final volume of $20 \mu \mathrm{L}$, which was pre-incubated on ice for $30 \mathrm{~min}$. The DNA-protein complexes were resolved by electrophoresis on an $8 \%$ polyacrylamide gel in $0.5 \mathrm{X}$ TBE buffer at $100 \mathrm{~V}$ for approximately $2 \mathrm{~h}$ at $4^{\circ} \mathrm{C}$. Gels were stained with $1 \mathrm{mg} / \mathrm{mL}$ ethidium bromide, de-stained in distillated water, and photographed using the DigiDoc-It ${ }^{\mathrm{TM}}$ Imaging System.

\section{RESULTS}

Electrophoretic behavior assays and in silico analyses was used by Lima Neto et al. (2014) to map eleven IBDSs that are related to the replication origins oriGNA13, oriC, ori $B$, and ori $A$ in the amplified domain of the $A M P D 2$ gene of the Chinese hamster. In this study, we mapped the INBDSs present in this region. 
In silico analysis of the amplified Chinese hamster $A M P D 2$ gene domain was performed using the Map15a program, and INBDSs related to oriGNAI3, ori $C$, ori $B$ and ori $A$ were mapped. The eleven INBDSs were detected in approximately $65 \mathrm{~kb}$ of the $A M P D 2$ gene domain (Figure 2): $n b 7$ and $n b 8$ for oriGNAI3; $n b 9, n b 10$, and $n b 11$ for oriC; $n b 1, n b 2$, and $n b 3$ for ori $B$; and $n b 4, n b 5$, and $n b 6$ for ori $A$. Table 2 lists the helical parameters for all mapped INBDSs. The helix parameter ENDS ratio (ratio of the contour length of the segments helical axis to the shortest distance between the fragments ends) indicated that all DNA sites have a straight structure (ENDS ratio $<1.10$ ) and right-handed superhelical writhe (positive roll), except for the sites $n b 4, n b 7$, and $n b 11$. The helical parameter twist showed values $\leq 34^{\circ}$, except for $n b 4, n b 7, n b 9$, and $n b 11$.
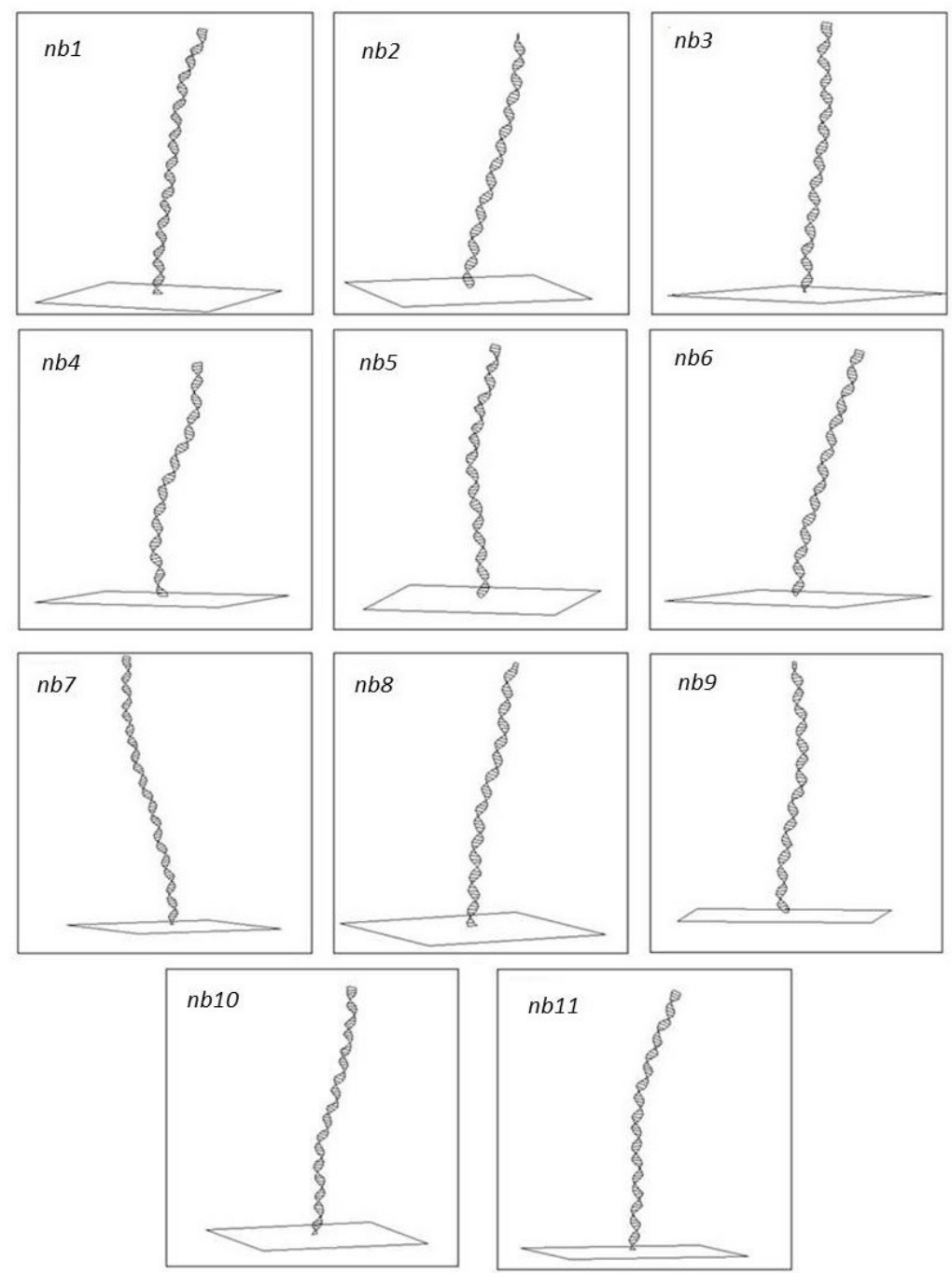

Figure 2. Schematic physical map of the amplified $A M P D 2$ gene domain showing non-bent DNA positions at each origin. Horizontal arrows indicate direction of transcription. 
Table 2. Helical parameters of INBDSs.

\begin{tabular}{l|c|c|c|c|c|c|c|c|c|c|c}
\hline INBDSs & $n b 1$ & $n b 2$ & $n b 3$ & $n b 4$ & $n b 5$ & $n b 6$ & $n b 7$ & $n b 8$ & $n b 9$ & $n b 10$ & $n b 11$ \\
\hline ENDS Ratio & 1.01 & 1.02 & 1.02 & 1.03 & 1.02 & 1.02 & 1.02 & 1.01 & 1.02 & 1.02 & 1.03 \\
\hline Roll & 0.48 & 0.77 & 0.11 & -0.40 & 0.09 & 0.56 & -0.19 & 1.09 & 0.02 & 0.40 & -0.31 \\
\hline Twist & 33.88 & 33.90 & 33.96 & 34.12 & 33.95 & 33.83 & 34.2 & 33.73 & 34.11 & 33.84 & 34.11 \\
\hline
\end{tabular}

From these analyses, we selected regions that showed sequences suitable for amplification (primers are listed in Table 1). For each non-bent DNA fragment that was selected, the two-dimensional projection of the three-dimensional route was obtained via the 3D15M1 program, allowing the molecular structure to be visualized (Figure 1). It was possible to observe the non- curve characteristics of all fragments selected.

To confirm the non-curve characteristics of the fragments, they were run on a $12 \%$ polyacrylamide gel without ethidium bromide. The $R$-value of each fragment was calculated to evaluate fragment mobility. All fragments showed no change in their mobility, with $R$-values between 0.90 and 1.10 (Table 3).

Table 3. INBDS and $R$-values.

\begin{tabular}{l|c|c|c|c|c|c|c|c|c|c|c}
\hline INBDS & $n b 1$ & $n b 2$ & $n b 3$ & $n b 4$ & $n b 5$ & $n b 6$ & $n b 7$ & $n b 8$ & $n b 9$ & $n b 10$ & $n b 11$ \\
\hline Fragment size (bp)* & 103 & 87 & 91 & 82 & 89 & 86 & 112 & 90 & 87 & 96 & 91 \\
\hline$R$-value & 0.97 & 0.97 & 0.92 & 0.99 & 0.91 & 0.97 & 1.02 & 0.95 & 0.96 & 0.95 & 1.00 \\
\hline
\end{tabular}

*Non-bent DNA fragment sizes after enzymatic cleavage.

In this study we investigated HMGB1 ability to bind to IBDSs and INBDs present in the amplified $A M P D 2$ gene domain. Figure 3 shows the results from the EMSA with oriGNAI3 samples $(b 1, b 2$, and $n b 7)$. It is clear that HMGB1 binds efficiently to all selected DNA fragments regardless of their bent or non-bent nature. Compared to the 123-bp positive control amplicon, we were unable to observe any significant difference in binding patterns of HMGB1protein to the analyzed fragments.

A

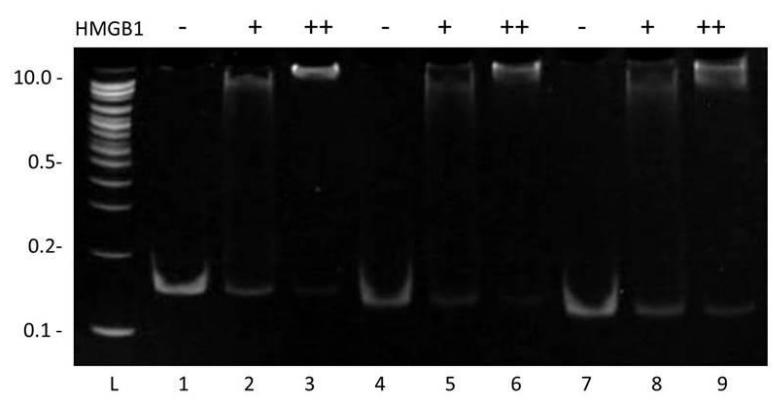

B

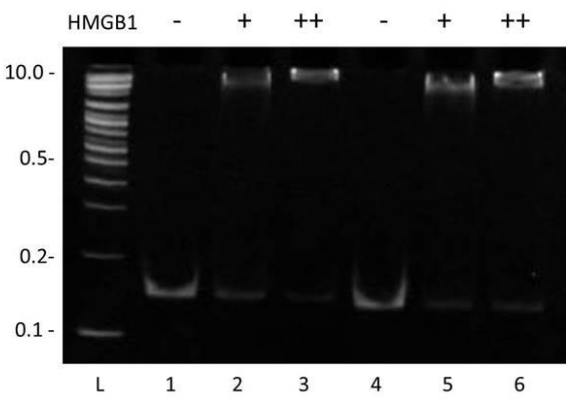

Figure 3. A. HMGB1 binding to IBDSs from oriGNAI3. B. HMGB1 binding to INBDS from oriGNAI3. For EMSA, increasing amounts of HMGB1 protein were incubated in the presence of the positive control (123-bp fragment; lanes 1 to $3, \mathbf{A}$ and $\mathbf{B}$ ), b1 (lanes 4 to $6, \mathbf{A}$ ), b2 (lanes 7 to $9, \mathbf{A}$ ), and $n b 7$ (lanes 4 to $6, \mathbf{B}$ ). DNA concentration in each reaction was $50 \mathrm{ng}$. The negative and positive signals indicate increasing concentrations of HMGB1 (0, 250, $500 \mathrm{ng})$ for each analyzed sample. L: 2-Log DNA Ladder (Biolabs). 
Figure 4 shows the results from the EMSA with oriC samples $(b 4 a, b 4 b$, and $n b 11)$. Here, we observed that HMGB1 was associated with all samples with no difference in ligation intensity between the samples.

A

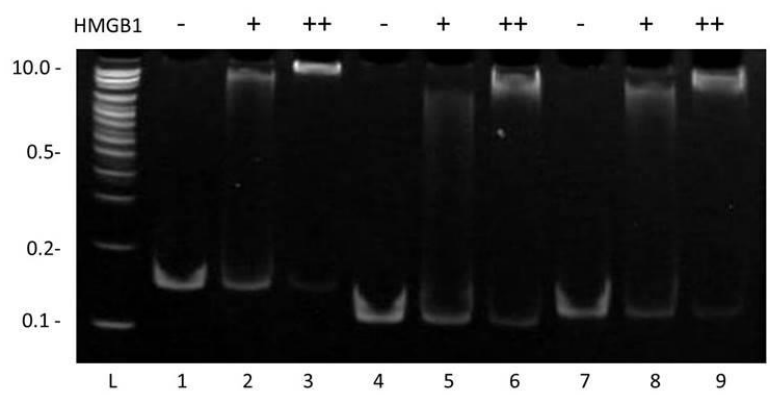

B

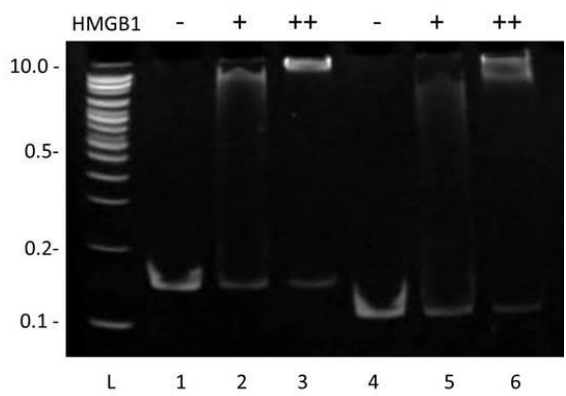

Figure 4. A. HMGB1 binding to IBDSs from ori $C$. B. HMGB1 binding to INBDS from ori $C$. For EMSA, increasing amounts of HMGB1 protein were incubated in the presence of the positive control (123-bp fragment; lanes 1 to 3 , A and $\mathbf{B}$ ), b4a (lanes 4 to $6, \mathbf{A}$ ), b4b (lanes 7 to 9, A), and $n b 11$ (lanes 4 to $6, \mathbf{B}$ ). DNA concentration in each reaction was $50 \mathrm{ng}$. The negative and positive signals indicate increasing concentrations of $\operatorname{HMGB} 1(0,250,500 \mathrm{ng})$ for each analyzed sample. L: 2-Log DNA Ladder (Biolabs).

The EMSA results from ori $B$ ( $b 5, b 6, n b 1$, and $n b 2)$, with all fragments being associated with HMGB1, are presented in Figure 5. When comparing $n b 2$ with the 123-bp positive control, a slight difference could be observed, as more free DNA was present in lane 9 than in lane 3 (positive control). This suggested that HMGB1 protein had lower affinity for this INBDS as compared to other samples.

A

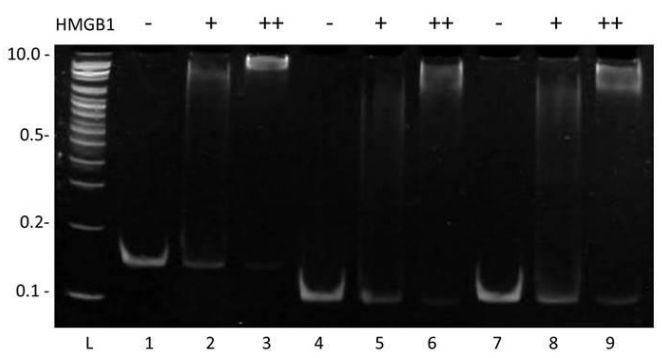

B

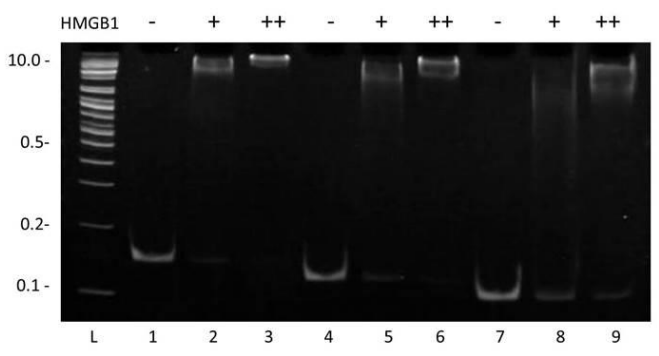

Figure 5. A. HMGB1 binding to IBDSs from ori $B$. B. HMGB1 binding to INBDS from ori $B$. For EMSA, increasing amounts of HMGB1 protein were incubated in the presence of the positive control (123-bp fragment; lanes 1 to 3, $\mathbf{A}$ and $\mathbf{B}$ ), b5 (lanes 4 to 6, A), b6 (lanes 7 to 9, $\mathbf{A}$ ), nb1 (lanes 4 to 6, B), and nb2 (lanes 7 to 9). DNA concentration in each reaction was $50 \mathrm{ng}$. The negative and positive signals indicate increasing concentrations of HMGB1 (0, 250, $500 \mathrm{ng}$ ) for each analyzed sample. . L: 2-Log DNA Ladder (Biolabs).

Figure 6 exhibits EMSA in oriA $(b 7, b 8, n b 4$, and $n b 5)$. Similarly, all fragments were associated with HMGB1. The non-bent fragments $n b 4$ and $n b 5$ showed a slight difference from the 123-bp positive control; this difference is more clear in $n b 5$. In these samples, free DNA (in lanes 6 and 9) was available in larger amounts when compared with the other samples in ori $A$. 
A

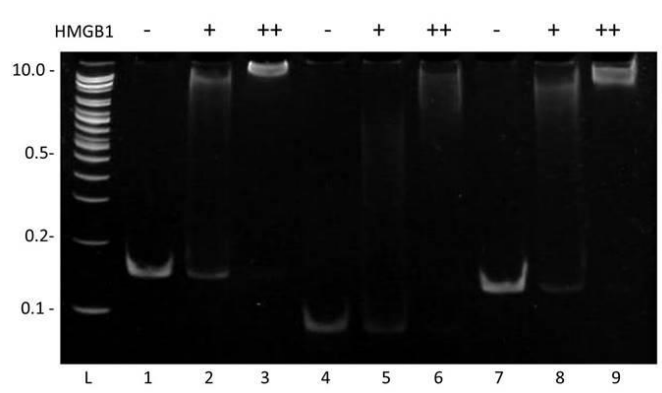

B

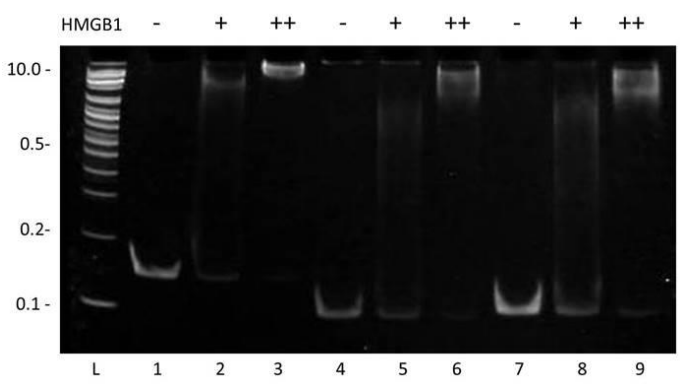

Figure 6. A. HMGB1 binding to IBDSs from oriA. B. HMGB1 binding to INBDS from ori $A$. For EMSA, increasing amounts of HMGB1 protein were incubated in the presence of the positive control (123-bp fragment; lanes 1 to 3, $\mathbf{A}$ and $\mathbf{B}$ ), b7 (lanes 4 to 6, A), b8 (lanes 7 to 9, $\mathbf{A}$ ), nb4 (lanes 4 to 6, B), and $n b 5$ (lanes 7 to 9). The DNA concentration in each reaction was $50 \mathrm{ng}$. The negative and positive signals indicate increasing concentrations of HMGB1 (0, 250, $500 \mathrm{ng})$ for each analyzed sample. L: 2-Log DNA Ladder (Biolabs).

\section{DISCUSSION}

The precise role of IBDSs found in sequences that direct nuclear processes such as formation of replication origins is not well established. However, it is known that some proteins could bind to these sequences and direct the DNA replication in a structure-dependent manner (Zhang et al., 2004). HMGB1 is involved in many biological processes, including transcription, replication, DNA repair, and maintenance of genome integrity. It has a clear preference for binding to noncanonical DNA structures (Stros, 2010).

Our results demonstrate that an increase in the concentrations of HMGB1 helped stabilize the complexes and prevented dissociation of the DNA fragments. Therefore, we saw differences in complex mobility when protein concentration was increased in EMSA. The HMGB1 protein showed cooperativity in HMGB1-DNA binding. It was previously shown that increase in the concentration of HMGB1 in the system facilitates DNA binding and results in the formation of ordered supramolecular complexes (Polianichko et al., 2002, 2013). The formation of these supramolecular complexes also explains the observed difference in complex mobility with increase in protein concentrations.

It is known that HMGB1 shows preferential binding to DNA with unusual conformations such as the fragments with IBDSs tested in this study. Both the A and B boxes of HMGB1 bind in the minor groove of DNA, but they exhibit differential activities. The A-box has much higher affinity for distorted DNA structures, whereas the B-box binds less selectively to distorted DNA structures. The B-box can introduce an approximately rightangled bend into linear DNA, in contrast to the A-box, which fails to bend DNA effectively (Thomas and Travers, 2001; Stros, 2010).

In all assays performed in this study, HMGB1 protein was efficiently associated with all tested samples, including non-bent fragments. Although INBDSs are straight DNA structures, HMGB1 protein can effectively bind to these fragments due to the ability of the B-box to bend DNA. Some non-bent fragments $(n b 2, n b 4$, and $n b 5)$ showed a slightly lower binding affinity, which may indicate that A and B boxes show reduced affinity to this type of straight DNA segment. 


\section{Conflicts of interest}

The authors declare no conflict of interest.

\section{ACKNOWLEDGMENTS}

Research supported by CAPES, Fundação Araucária and Secretaria de Estado da Ciência, Tecnologia e Ensino Superior - FUNDO PARANÁ. We thank Dr. Marcelo Rosado Fantappié (Instituto de Bioquímica Médica/UFRJ) for providing the HMGB1 expression vector and Dr. Michelle Debatisse (Institute Curie, Paris, France) for providing the amplified region of the AMPD2 gene. We also thank Valmir Peron and Marli Licero Schuete Silva for their dedicated technical assistance and Universidade Estadual de Maringá facilities (COMCAP Laboratories).

\section{REFERENCES}

Agresti A and Bianchi ME (2003). HMGB proteins and gene expression. Curr. Opin. Genet. Dev. 13: 170-178. http:// dx.doi.org/10.1016/S0959-437X(03)00023-6

Anderson JN (1986). Detection, sequence patterns and function of unusual DNA structures. Nucleic Acids Res. 14: 85138533. http://dx.doi.org/10.1093/nar/14.21.8513

Anglana M, Apiou F, Bensimon A and Debatisse M (2003). Dynamics of DNA replication in mammalian somatic cells: nucleotide pool modulates origin choice and interorigin spacing. Cell 114: 385-394. http://dx.doi.org/10.1016/ $\underline{\mathrm{S} 0092-8674(03) 00569-5}$

Bianchi ME and Agresti A (2005). HMG proteins: dynamic players in gene regulation and differentiation. Curr. Opin. Genet. Dev. 15: 496-506. http://dx.doi.org/10.1016/j.gde.2005.08.007

Blow JJ and Gillespie PJ (2008). Replication licensing and cancer--a fatal entanglement? Nat. Rev. Cancer 8: 799-806. http://dx.doi.org/10.1038/nrc2500

Bolshoy A, McNamara P, Harrington RE and Trifonov EN (1991). Curved DNA without A-A: experimental estimation of all 16 DNA wedge angles. Proc. Natl. Acad. Sci. USA 88: 2312-2316.http://dx.doi.org/10.1073/pnas.88.6.2312

de Oliveira FM, de Abreu da Silva IC, Rumjanek FD, Dias-Neto E, et al. (2006). Cloning the genes and DNA binding properties of High Mobility Group B1 (HMGB1) proteins from the human blood flukes Schistosoma mansoni and Schistosoma japonicum. Gene 377: 33-45. http://dx.doi.org/10.1016/j.gene.2006.03.001

Debatisse M, Toledo F and Anglana M (2004). Replication initiation in mammalian cells: changing preferences. Cell Cycle 3: 19-21.http://dx.doi.org/10.4161/cc.3.1.628

Eckahl TT and Anderson JN (1987). Computer modelling of DNA structures involved in chromosome maintenance. Nucleic Acids Res. 15: 8531-8545.http://dx.doi.org/10.1093/nar/15.20.8531

Eckahl TT and Anderson JN (1990). Conserved DNA structures in origins of replication. Nucleic Acids Res. 18: 16091612.http://dx.doi.org/10.1093/nar/18.6.1609

Fiorini A, Basso LR, Jr., Paçó-Larson ML and Fernandez MA (2001). Mapping of intrinsic bent DNA sites in the upstream region of DNA puff BhC4-1 amplified gene. J. Cell. Biochem. 83: 1-13. http://dx.doi.org/10.1002/jcb.1188

Fiorini A, de Gouveia FS, de Soares MA, Stocker AJ, et al. (2006a). DNA bending in the replication zone of the C3 DNA puff amplicon of Rhynchosciara americana (Diptera: Sciaridae). Mol. Biol. Rep. 33: 71-82. http://dx.doi. org/10.1007/s11033-006-0009-4

Fiorini A, Gouveia FdeS and Fernandez MA (2006b). Scaffold/matrix attachment regions and intrinsic DNA curvature. Biochemistry (Mosc.) 71: 481-488.http://dx.doi.org/10.1134/S0006297906050038

Gimenes F, Takeda KI, Fiorini A, Gouveia FS, et al. (2008). Intrinsically bent DNA in replication origins and gene promoters. Genet. Mol. Res. 7: 549-558. http://dx.doi.org/10.4238/vol7-2gmr461

Grasser KD, Launholt D and Grasser M (2007). High mobility group proteins of the plant HMGB family: dynamic chromatin modulators. Biochim. Biophys. Acta 1769: 346-357. http://dx.doi.org/10.1016/j.bbaexp.2006.12.004

Hock R, Furusawa T, Ueda T and Bustin M (2007). HMG chromosomal proteins in development and disease. Trends Cell Biol. 17: 72-79. http://dx.doi.org/10.1016/j.tcb.2006.12.001

Homberger HP (1989). Bent DNA is a structural feature of scaffold-attached regions in Drosophila melanogaster interphase nuclei. Chromosoma 98: 99-104. http://dx.doi.org/10.1007/BF00291044 
Lima Neto QA, Rando FS, Freitas DVB, Rodrigues LF, et al. (2014). Straight core structure of DNA replication origins in the mammalian AMPD2 locus. Biochemistry (Mosc.) 79: 37-43.http://dx.doi.org/10.1134/S0006297914010064

Milot E, Belmaaza A, Wallenburg JC, Gusew N, et al. (1992). Chromosomal illegitimate recombination in mammalian cells is associated with intrinsically bent DNA elements. EMBO J. 11: 5063-5070.

Mollegaard NE, Lindemose S and Nielsen PE (2005). Uranyl photoprobing of nonbent A/T- and bent A-tracts. A difference of flexibility? Biochemistry 44: 7855-7863. http://dx.doi.org/10.1021/bi0502083

Norberto de Souza O and Ornstein RL (1998). Inherent DNA curvature and flexibility correlate with TATA box functionality. Biopolymers 46: 403-415.http://dx.doi.org/10.1002/(SICI)1097-0282(199811)46:6<403::AID-BIP5>3.3.CO;2-1

Palin AH, Critcher R, Fitzgerald DJ, Anderson JN, et al. (1998). Direct cloning and analysis of DNA sequences from a region of the Chinese hamster genome associated with aphidicolin-sensitive fragility. J. Cell Sci. 111: 1623-1634.

Pasero P, Sjakste N, Blettry C, Got C, et al. (1993). Long-range organization and sequence-directed curvature of Xenopus laevis satellite 1 DNA. Nucleic Acids Res. 21: 4703-4710. http://dx.doi.org/10.1093/nar/21.20.4703

Polianichko AM, Chikhirzhina EV, Skvortsov AN, Kostyleva EI, et al. (2002). The HMG1 ta(i)le. J. Biomol. Struct. Dyn. 19: 1053-1062. http://dx.doi.org/10.1080/07391102.2002.10506808

Polianichko AM, Vorob'ev VI and Chikhirzhina EV (2013). [The structure of the complexes of DNA with nonhistone chromosomal protein HMGB1 and the histone $\mathrm{H} 1$ in the presence of manganese ions. II. Vibrational circular dichroism spectroscopy]. Mol. Biol. (Mosk.) 47: 338-346.

Ribeiro FS, de Abreu da Silva IC, Carneiro VC, Belgrano FdosS, et al. (2012). The dengue vector Aedes aegypti contains a functional high mobility group box 1 (HMGB1) protein with a unique regulatory C-terminus. PLoS One 7: e40192. http://dx.doi.org/10.1371/journal.pone.0040192

Sambrook J and Russell DW (2001). Molecular cloning: A laboratory manual. 3rd edn. Cold Spring Harbor Laboratory Press, Cold Spring Harbor, New York.

Segal E and Widom J (2009a). From DNA sequence to transcriptional behaviour: a quantitative approach. Nat. Rev. Genet. 10: 443-456. http://dx.doi.org/10.1038/nrg2591

Segal E and Widom J (2009b). What controls nucleosome positions? Trends Genet. 25: 335-343.http://dx.doi.org/10.1016/j. tig.2009.06.002

Shen Z (2011). Genomic instability and cancer: an introduction. J. Mol. Cell Biol. 3: 1-3. http://dx.doi.org/10.1093/jmcb/mjq057

Stros M (1998). DNA bending by the chromosomal protein HMG1 and its high mobility group box domains. Effect of flanking sequences. J. Biol. Chem. 273: 10355-10361.

Stros M (2010). HMGB proteins: interactions with DNA and chromatin. Biochim. Biophys. Acta 1799: 101-113. http:// dx.doi.org/10.1016/j.bbagrm.2009.09.008

Stros M, Stokrová J and Thomas JO (1994). DNA looping by the HMG-box domains of HMG1 and modulation of DNA binding by the acidic C-terminal domain. Nucleic Acids Res. 22: 1044-1051.http://dx.doi.org/10.1093/nar/22.6.1044

Thomas JO and Travers AA (2001). HMG1 and 2, and related 'architectural' DNA-binding proteins. Trends Biochem. Sci. 26: 167-174. http://dx.doi.org/10.1016/S0968-0004(01)01801-1

Toledo F, Baron B, Fernandez MA, Lachagès AM, et al. (1998). oriGNAI3: a narrow zone of preferential replication initiation in mammalian cells identified by $2 \mathrm{D}$ gel and competitive PCR replicon mapping techniques. Nucleic Acids Res. 26: 2313-2321.http://dx.doi.org/10.1093/nar/26.10.2313

Tourrière H and Pasero P (2007). Maintenance of fork integrity at damaged DNA and natural pause sites. DNA Repair (Amst.) 6: 900-913.http://dx.doi.org/10.1016/j.dnarep.2007.02.004

Virstedt J, Berge T, Henderson RM, Waring MJ, et al. (2004). The influence of DNA stiffness upon nucleosome formation. J. Struct. Biol. 148: 66-85.http://dx.doi.org/10.1016/j.jsb.2004.03.007

Zhang Y, Xi Z, Hegde RS, Shakked Z, et al. (2004). Predicting indirect readout effects in protein-DNA interactions. Proc. Natl. Acad. Sci. USA 101: 8337-8341.http://dx.doi.org/10.1073/pnas.0402319101 